\title{
GOLDEN EAGLE ATTEMPTS TO KILL SANDHILL CRANE
}

BRIAN W. JOHNS, Canadian Wildlife Service, 115 Perimeter Road, Saskato Saskatchewan S7N 0X4

In October eagl'es congregate along the South Saskatchewan River southwest of Lacadena, Saskatchewan. There were 48 on October 17, 1974 and probably more than 50 on October. 28; 1976. In 1974, 1975 and 1976, eagles were observed feeding on ducks and geese. Never had a kill by one of these birds been witnessed although D. N. Nieman watched an adult Golden Eagle stoop unsuccessfully on 12 flying Canada Geese on Octciber 13, 1976, while flying a waterfowl survey in the area. Kuyt has observed Golden Eagles attack White-fronted Geese. ${ }^{2}$

Walkinshaw indicates "that eagles often attack cranes in Nebraska", however, Bent does not mention the Sandhill Crane as a food item of Golden Eagles. ${ }^{3} 1$ On October 4, 1976, I saw a Golden Eagle attempting to kill a crane adjacent to a loafing and roosting slough used by Sandhill Cranes, Mallards, White-fronted, Snow and Canada geese near Lacadena.

By 1430 I was within $0.4 \mathrm{~km}$ of about 3,000 cranes and 5,000 geese feeding on an oat stubble field. At 1431 all the birds began rising, milling about and landing $0.2-1.6 \mathrm{~km}$ away in stubble and summerfallow. While scanning the field as the birds were flushing, an immature Golden Eagle was observed on the ground $10 \mathrm{~m}$ from an apparently injured adult Sandhill Crane. The crane was flopping on the ground unable to stand or fly.

A strong $65 \mathrm{~km} / \mathrm{h}$ wind was blowing and the eagle spread its wings, caught the wind and soared above the crane as hundreds of cranes and geese soared overhead. The eagle rose to a height of about $15 \mathrm{~m}$, stooped and hit the crane lightly on the back. Then it landed and clawed, pecked and

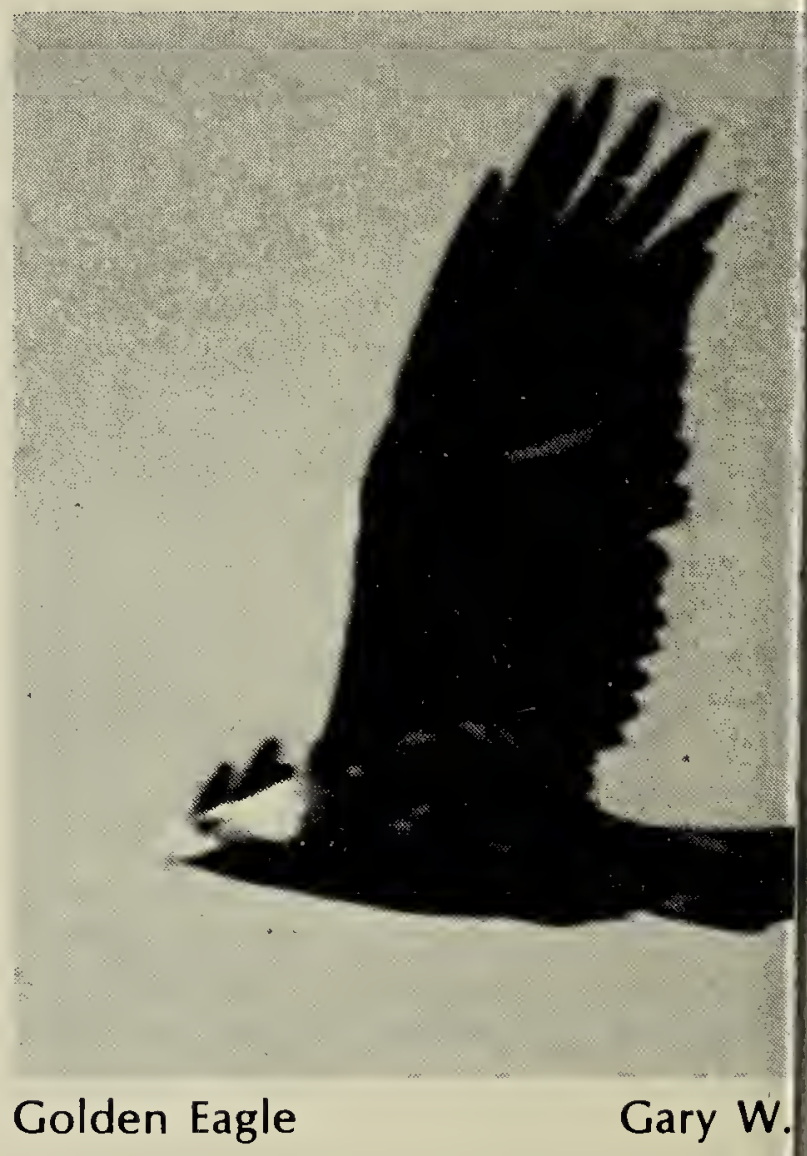

flapped its wings at the crane $n$ also flapped and stabbed back a eagle. This fight continued for a 30 seconds before the crane tri stand, only to fall back to the gro

The eagle again took off bu time landed about $70 \mathrm{~m}$ away the stricken crane. It began wa and hopping towards the crani stopped at 1437 about $64 \mathrm{~m}$ Meanwhile the crane was mainta a low, spreadwing posture with down and neck outstretched. minutes later the eagle moved closer and paused for a minute $b$ flying again and landing next $t$ crane. As the eagle alighted crane raised its wings and with th of the strong wind was able to gi borne. It flew against the towards the roosting slough, $\operatorname{tr}$ one leg which appeared to be bi close to the body. 
ie feeding cranes and geese had ied at the eagle's last flight and ed above it. The eagle then flushnd flew to the southwest through milling and flushing birds and out ght at 1448.

1520 the wounded crane was ted with the spotting scope. It was on the slough about $45 \mathrm{~m}$ from e, on ice near open water with its s spread. As the ice was thin, it impossible for me to reach the

cause the initial contact between and crane was not observed, I do not know whether the eagle was preying on a wounded crane or if the bird's injuries resulted from the eagle's attack.

${ }^{1}$ BENT, A. C. 1961. Life histories of North American birds of prey. Part 1. Dover, Inc., New York. 409 pp.

${ }^{2}$ KUYT, E. 1974. Golden Eagles attack White-fronted Geese. Blue Jay 32: 227-228.

${ }^{3}$ WALKINSHAW, L. H. 1949. The Sandhill Cranes. Bull. 29 Cranbrook Inst. Sci., Bloomfield Hills, Mich. 202 pp.

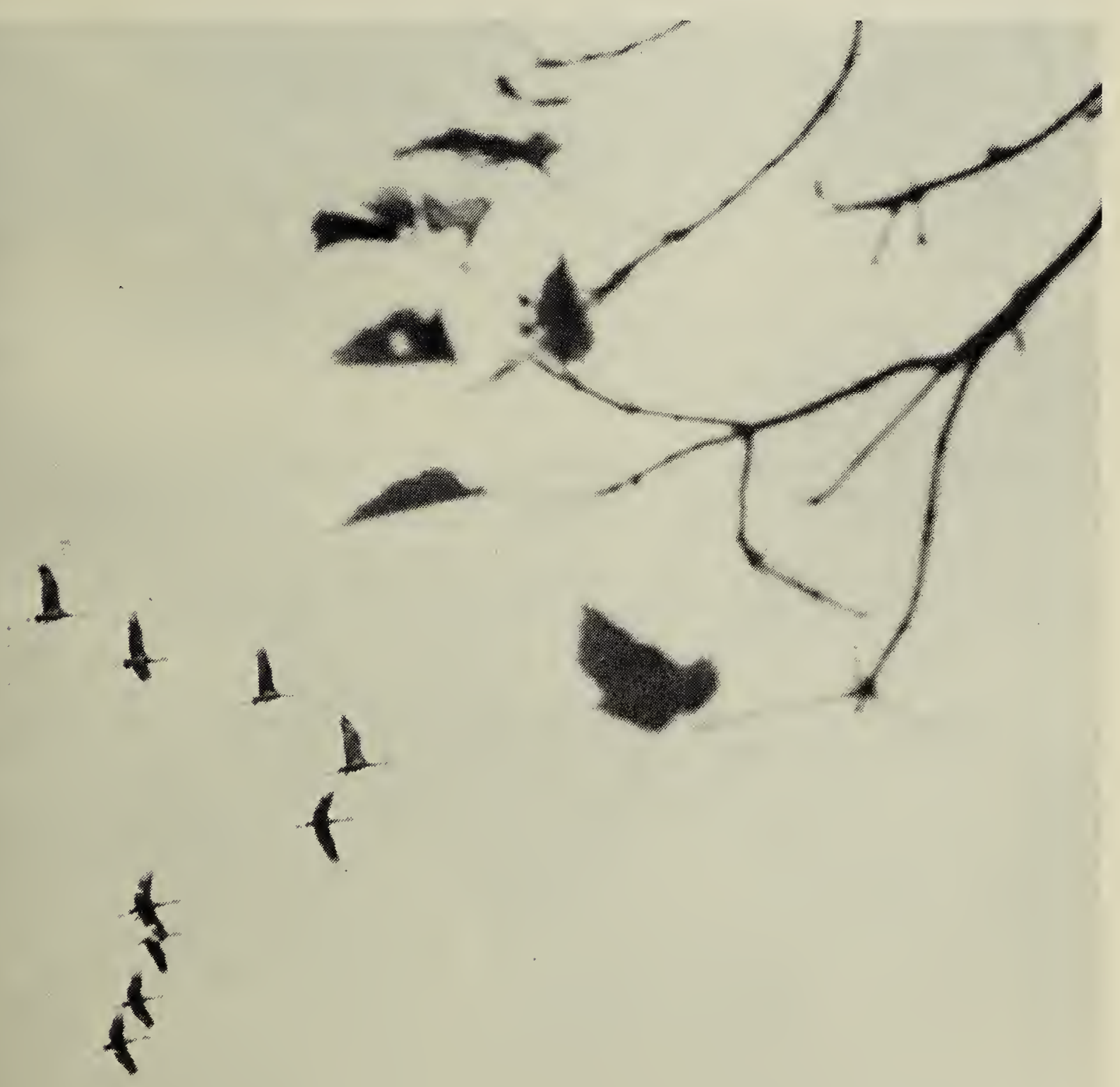

ill Cranes 